\title{
The effects of political liberalization on security
}

\author{
Brent E. Sasley
}

$\mathrm{T}$

HE END OF bipolarity brought to light the difficulty inherent in using Cold War concepts of security to explain international relations in the developing world. As well, it has often been argued that international relations is basically an American (with some British input) enterprise (Azar and Moon, 1988b: 1; Hoffman, 1977), with the consequences that only threats that concerned American interests (i.e. military threats from the Soviet Union) were considered security threats. ${ }^{1}$ In the contemporary international system, however, issues of security are now much more than superpower competition and interests, and these raise questions as to the nature and practice of security (Dalby, 1997: 4). As Brian Job notes, 'it is increasingly taken for granted that the world is a secure place for First World [i.e. developed] states and their citizens', while the same is not true for developing world countries (Job, 1992: 11).

This chapter's purpose is to broaden the definition of security by including regimes and societies as essential referent objects of security. Demands for social, economic and political rights across the Middle East have threatened the positions, indeed the very safety and perhaps even the survival, of regimes that have been in power for many years. Focusing on the Arab world, these demands are the result of declining socio-economic conditions within the region. Efforts to placate such appeals, previously effected by focusing attention on foreign policy agendas, through political reforms are perceived by these regimes as undermining their security. In response, regimes have engaged in repression, which in turn undermines the security of their societies not only through violence and ill-treatment, but by not allowing the requisite reforms to take place - thus ignoring the socio-economic plight of their citizens. As a vicious circle, this has the effect of angering populations even more, so that demands for change become more strident, more common and, perhaps eventually increasingly violent. This contributes to increased regime insecurity. Thus, the sense of threat that prevails in the developing world (within the state) is to and from the regime in power. 
To that end, the chapter is set out in the following manner. The first part is a clarification of the difference between political liberalization and democratization, as the two processes, though related, are distinct. The second section formulates the theoretical arguments of this chapter, namely that regimes and societies are two important referent objects of security which, though neglected by traditional security studies literature, are consequential; and that the two are inextricably linked. This is followed by the chapter's empirical case study, the Palestinians and the Palestinian Authority. Finally, the conclusion offers some preliminary thoughts on the usefulness of this addition to security studies in the light of the Middle Eastern context.

\section{Political liberalization versus democratization}

It is necessary first to make a distinction between liberalization and democratization, since they are different processes. One important study on this topic differentiates between the two as follows: political liberalization 'involves the expansion of public space through the recognition and protection of civil and political liberties, particularly those bearing upon the ability of citizens to engage in free political discourse and to freely organize in pursuit of common interests'; whereas political democratization is defined as 'an expansion of political participation in such a way as to provide citizens with a degree of meaningful collective control over public policy' (Brynen, Korany and Noble, 1995: 3).

Many Middle Eastern states have engaged in some democratic forms, primarily focused around elections. ${ }^{2}$ This is a Dahlian notion of democracy, however, that relies on procedural aspects to determine whether a state is democratic or not (Dahl, 1971). However, since these elections are not always regular or fair, and because in many cases their gains have been offset by other legal and political manoeuvrings by regimes to negate their effects, the term 'democratization' will not be used. Liberalization is a much more suitable term, since it implies political openings that can include a variety of forms and aspects, and can take place in some areas but not others. Augustus Richard Norton defines liberalization as 'reformist measures to open up outlets for the free expression of opinion, to place limits on the arbitrary exercise of power, and to permit political association' (Norton, 1995: 33). Efforts in this vein, he contends, have been made in the Middle East, while steps towards democratization have not. Other authors agree that liberalization can take place without democratization (Linz and Stepan, 1996: 16). Following these definitions, the term 'liberalization' will be used, as it corresponds to reality in the Middle East more so than 'democratization'. ${ }^{3}$

A caveat should be added here. There is inherent in any examination of political reform in non-Western countries a danger of ethnocentricity, especially concerning levels of democracy; or of 'reading processes deriving from one 
specific set of historical and political circumstances into other, very different, contexts' (Brynen, Korany and Noble, 1995: 3). To overlay Western values of democracy onto a region such as the Middle East, which has experienced completely distinct economic, political, cultural, religious and geostrategic conditions, is to risk analysing levels of political liberalization according to Western standards. This simply should not be the case, as the conditions and time frame under which North American and European democracy evolved do not compare to Middle Eastern conditions. ${ }^{4}$ Despite this, and without wading into the debate on the ability of the Middle East to democratize, this chapter takes the values of political liberalization as 'good', insofar as such reforms contribute to the security of people. At least one Palestinian politician and scholar believes that democracy's Western origins should not be bothered with, since it has by now become a 'universal value in itself [and] many of its principles and attributes have assumed a global character and relevance' (Abu-Amr, 1996: 93).

\section{Inside the black box: the necessity of other referent objects of security}

In an effort to defend the more realist notions of security studies, Stephen Walt wrote that the main focus of security studies is the phenomenon of inter-state war (Walt, 1991:212). Fred Halliday argued that international relations is about 'relations between states, war, power, the intersection of military and economic interests' (Halliday, 1995: 733). The question to be asked is whether such definitions of security account for international politics across the world - and the answer must be 'no'. Primarily, this is because the overwhelming number of violent conflicts that have occurred since the end of the Second World War has taken place in the developing world. Moreover, these conflicts have been mainly intra-state (Ayoob, 1997; Holsti, 1991). These very statistics call into question the utility of the rational, unitary, realist state focused on external military threats, and therefore indicate a need for a redefinition of security.

Simon Dalby points out that 'security as conventionally formulated is about the protection of a political community of some sort' (1997: 9). From this, the realists took the notion that political community referred only to states, since they were the most important actors in the international system and the primary referent objects of security. ${ }^{5}$ By designating states as 'black boxes', realism ignores the series of complex interactions within states, and the 'individual' nature of people, or citizens; instead, it constructs security around the notion that people are citizens of states - hence, their security is protected by, and tied into that of, the state itself, as represented by regimes (Krause and Williams, 1997: 43).

The liberal paradigm is generally also not helpful, since although it rejects the idea of a black box, it looks at domestic politics mainly as an explanation for 
state behaviour. The overwhelming politics of security in the developing world is not, however, conditioned around inter-state relations: the politics of security concerns the internal contests for security within states.

As well, norms have arisen since the beginning of the 1990s that are becoming much more global in their acceptability and applicability than anything that appeared during the Cold War (although, perhaps predictably, these norms begin within the Western world as much as any of the more traditional security norms did) - namely, that repression of populations can no longer be justified in the name of 'security' (bipolar rivalry or any other). Thus, the populations that realism assumed were protected by the state are in fact facing insecurity because of the state. Because this occurs overwhelmingly in the developing world, 'critical security studies cannot ignore the politics of security provision in differing political circumstances' (Dalby, 1997: 23).

All this questions the claims of the state to realist types of sovereignty, from which flow their particular conceptions of security (Krause and Williams, 1997: 45). The disjuncture between state and society leads to Ken Booth's question: how can states be the primary referent objects of security, when not all states are in the business of providing security - and in fact may provide the opposite, namely insecurity? (Booth, 1991: 320). Security, Barry Buzan points out, is not about power - as it had been primarily conceptualized during the Cold War - but rather is about actual security from threats (Buzan, 1991: 3). Quite simply, 'overt violence and conflict aside, most developing countries have become insecure places to live' (Azar and Moon, 1988b: 3). That is because of the insecurity faced by populations themselves, not by states. Since, in the developing world, states face far fewer threats than societies or regimes (from each other), the Cold War conception of security must be broadened to include these referent objects as well. We must therefore separate the various referent objects of security by asking whose security is affected - the state's, the regime's, or society's, particularly since frequently certain types of security are affected while others are not (see Job, 1992: 15).

By redefining the object of security from the state to the individual or the regime, or to populations or communal groups as themselves, allows them to become important factors of consideration in a (necessarily) comprehensive analysis of security. An examination of regime-society relations in the developing world in general and the Middle East in particular highlights the inadequacies of traditional formulations of security.

\section{Regime security}

One of the most important referent objects of security in the developing world must be the regime that governs the state; yet, it is also one of the least studied elements of security in the critical studies literature, in comparison to security 
studies on gender or intra-state communal group conflicts. In conventional security studies, where conceptions of security are formulated around interstate relations, the state is understood in its Weberian sense, as an actor in the international system with a centralized authority controlling a recognized territory. In the developed world, ${ }^{6}$ this is appropriate, since there democratic modes of governance depend on the separation between governments and the state; that is, governments can change, but they all still use the same state institutions to conduct policy. Moreover, as these governments are dependent on electoral votes to remain in power, they must use these institutions to make policy to the electorate's satisfaction. Here, the 'rules of the game' delineate who takes power and when it is given up.

But this does not correlate with developments in non-Western areas. Instead, regimes that come to power do not leave power willingly, if they leave at all. In instances of power sharing, or power grabbing, the rules are not clear - if there even are rules - or the rules exclude various groups and ideologies (i.e. those who do not agree with the authoritarian nature or the policies of the regime in power). ${ }^{7}$ In the meantime, incumbent regimes construct and control state institutions for their own benefits more than for the benefits of their populations. These include both political and security institutions (such as secret policy and intelligence agencies; see Ayoob, 1997). This occurs to the extent that, when examining domestic circumstances, the regime becomes identical to the state, and the difference between state and regime becomes negligible (see Ayoob, 1997: 130). ${ }^{8}$ Thus, regime security is a concept more applicable to the developing world - as are most of the reformulations of security in the post-Cold War theoretical and practical arenas.

In the Middle East, most regimes are associated with the state - whether tied together through familial, tribal, ethnic or religious links, or through shared interests, they utilize the state's apparatuses, coercive and others, to protect their interests, ${ }^{9}$ to the point where regime and state become identical. ${ }^{10} \mathrm{Be}-$ cause of this, pressures for liberalization threaten to weaken the legal and political foundations that regimes base their positions of power (i.e. their security) on. ${ }^{11}$

During the 1980s and early 1990s, many Arab governments initiated liberalization efforts, including Egypt, Yemen, Jordan and the Maghreb states (Algeria, Tunisia, and Morocco), to varying degrees. Yet the reasons behind such reforms are as important as the reforms themselves, for what they tell us about security. Regime security has been defined as the "maintenance of the core values of the regime, especially maintenance of its basic rules and institutions' (al-Sayyid, 1999: 48), without which the regime cannot survive. To this should also be added the safety and survival of the members of the regime. $^{12}$ 
Regime security can be affected by society taking up arms against it, due to its inability to look after society's basic needs, or at least to provide effective channels through which citizens feel they can have their concerns heard and responded to. Even without resorting to armed confrontation, citizens might withdraw passive support from the regime, in the form of civil disobedience or non-voluntary co-operation, which might sap the regime of its resources, and certainly of its legitimacy.

Demands for economic liberalization are equally dangerous for regimes, because they can lead to demands for political change. As sectors of the economy benefit from its liberalization (through less state interference in the economy), groups become empowered through greater prosperity. This leads them to desire more freedoms, necessary for the free market and their own generation of wealth, such as access to information and the right to associate. As well, they will demand a greater say in policy-making.

The end result of these demands is that they increase perceptions of regime insecurity. To ameliorate such concerns, regimes can choose one of two options. First, they can adopt liberalization efforts, in what one scholar has termed selfpreservation 'survival strategies'. Here, 'the goal of a political survival strategy is to open up the political arena to a degree of participation sufficient to attract support from groups with an interest in political reforms ... without at the same time creating conditions that might give these groups a means to undermine the hegemony of the ruling elites' (Brumberg, 1995: 235; see also Norton, 1995: 3). ${ }^{13}$

The second option springs from the regime's belief that any liberalization efforts will only endanger it further. Never having been accountable to their citizens in the past, regimes fear what could happen if they do become accountable. Instead of finding out, they opt to use their control of state institutions to repress, if not crush outright, any agitation for change. This has been the case in Arab countries such as Syria and Iraq.

There are security problems with both of these options. In the first case, popular dissatisfaction with the regime has often been cited as one of the main reasons behind the liberalizations (Kazemi and Norton, 1999; Ibrahim, 1995; Brynen, 1992; Hudson, 1991: 424-425). Consequently, regimes that have liberalized do not hold any belief in the inherent value of reforms, and only view them as a strategy, or a means to an end - namely the furthering of their own security. Thus their commitment to these reforms is fragile, with the consequent possibility that once regimes perceive the threat to be effectively dealt with, they will roll back such reforms. Alternatively, if they perceive that reforms have only created the conditions for more demands for change, they will forego this option as too dangerous to their security. 
At the same time, by utilizing the second option, regimes not only create insecurity for society (see below), they also harden opposition to the regime and may even force adversaries to use their own forms of violence against the regime. Many militant Islamic groups have followed this strategy.

\section{Societal security}

Societal security ${ }^{14}$ can be defined as the "protection of the core values of that society, namely, protecting the right to life of its citizens, safeguarding its national values, and ensuring its welfare, or at least satisfaction of the basic needs of its inhabitants' (al-Sayyid, 1999: 48). National values, while important, are not relevant here because the focus is on society's security from the regime, which itself normally formulates such national values.

This definition of societal security does not refer specifically to ethnicity or any other communal distinction (though it clearly does apply to such distinctions) and the effects it has on intra-state conflict. Such a locus takes up much of the critical security studies literature, which distinguishes this intra-state war from the conventional inter-state security dilemmas. But societal security is not just about intra-state war, though it is equally important and relevant. Rather, the idea here is that the security of societies, or segments of societies, or individuals, can be affected by the state/regime itself. ${ }^{15}$

The object of security must also be individuals as individuals, not only as parts of the whole (the state) - people are to be secured as individuals, or as societies. Realist or other systemic theories' focus on the state simply preclude this type of conception, since the black box of the state need not be examined in order to determine why states behave as they do - which is the primary, if not only, focus of structural or systemic theories. According to this redefinition of security, the state cannot, or does not, provide security for its citizens, because it may be the source of that very insecurity. ${ }^{16}$ In such cases, the state itself, as wielder of the most effective forms of coercion and violence within its territory, provides the most serious threats to society.

In the Middle East, societies have long been in danger from their own governments. This is a direct result of the lack of control societies have over policy making in their countries, which in turn flows from the lack of accountability of Arab regimes to their citizens. A 1998 Middle East Report summary, for example, declared that despite several multiparty elections in the region, executive authority remained an uncontested position, that vote-rigging was common, and that political opposition had restrictions placed on it that seriously hampered its ability to freely compete. The report also pointed out that parliamentary elections in the Middle East are designed in such a way that usually guarantees the regime the most support (Middle East Report, 
1998). Lack of effective opposition to the state means a lack of ability to influence policy.

The 'resurrection' of civil society in the Arab world - particularly since the end of the 1980s and beginning of the 1990s - is a good indicator of the increasing demands being made on Arab regimes, and the efforts by society to have its needs met. Characterized as the autonomous space between state and society, and effective as a buffer against the state, civil society is considered vital for democracy, as it

protects the individual against possible hegemony by the state, creates channels of communication between rulers and ruled, contributes to the dissemination of views independent from those in power, fosters initiative and responsibility-taking, and provides avenues through which the population can make its voice heard, participate in public life, lobby the state, and force the government to account for its actions. (Denoeux, 1996: 32)

The ability of civil society to function properly and effectively within a given space is an integral aspect of political liberalization, both in terms of being allowed this space in which to flourish, and because a stronger civil society is better able to push for political reforms and thus increase societal security. The very growth of civil society highlights the need and desire for these changes.

In the second half of the twentieth century, the Arab states expanded in the name of modernization, at the expense of civil society. In the current conditions, as the state retreats, unable to fulfil its obligations to its citizens, civil society is filling the gap (though not necessarily all of it). Islamist movements have been particularly effective because of their social welfare problems and the tug on the emotional-psychological bond people have toward their religion, particularly during times of hardship. ${ }^{17}$

But increased social mobilization endangers regimes that have historically ignored societal security by relying instead on religious or historical symbols and emotions (Azar and Moon, 1988a: 81), or foreign policy distractions to deflect internal concerns. This crisis of legitimacy puts regimes in danger. Irregular political processes based, for example, on 'hereditary political succession, along with repressive and arbitrary political rule based on the personal whim of rulers, deepen the legitimacy crisis and reinforce the vicious cycle of societal insecurity' (Azar and Moon, 1988a: 82). Regime backlashes against militant Islamic groups, for example, affect all elements of civil society, as governments undertake to quash all pressures for change (Sivan, 1997).

There is a vibrant civil society in most, if not all, Arab countries in the Middle East, but it is constantly in danger from the regime. Its existence proves that populations in the region do want to play a role in determining domestic policy, and are not so content under authoritarian rule (Schwedler, 
1995: 24). However this does not translate into government willingness to acquiesce in these desired changes; in fact, as noted above, regimes are more likely to either ignore these demands or respond harshly to them. Such conditions create the cycle of insecurity that characterizes much of the developing world.

\section{The regime-societal insecurity loop}

In the developing world, regime security and societal security are not often the same (al-Sayyid, 1999: 48). Regimes pursue their narrower interests at the expense of the majority of their populations. As Buzan, Waever and de Wilde point out, 'only rarely are state and societal boundaries coterminous' (1998: 119). The Middle East is a prime example of this, where the legacy of colonialism left various ethnic, linguistic or religious groups lumped together under a single authority in a single territory.

Yet the two are inextricably linked together. The growth of civil society and its ability to help pressure governments into initiating liberalizing reforms have placed increasing demands on the state, at the same time as the state is less able to effectively respond to these demands and needs. In turn, this creates a sense of insecurity for governments, who worry that such demands will undermine the foundations upon which they have built their regimes. Most often, they respond by repressing these pressures, thus creating insecurity for their societies. The result can be called the regime-societal insecurity loop - similar, in a sense, to the security dilemma realists note is present in the anarchic international system, though there are clear differences. Another way of putting it can be taken from Dalby's idea that 'in the process of providing various forms of security, insecurities are also reproduced, often in ways that either actually undermine the initial production of security or that merely perpetuate the problems to which they are supposedly providing solutions' (Dalby, 1997: 12; emphasis added). Although he is not referring specifically to regime security, Dalby's conception is relevant and appropriate.

An essential part of this loop is the perception that regimes have of their popular legitimacy, the loss of it, and the measures they take to rectify matters. ${ }^{18}$ In the developing world, the existence of a plurality of communal groups within the state means the regime usually lacks the support of some parts of society, perhaps even a majority, since it represents the interests of only specific groups or sectors. This automatically translates into a lack of widespread legitimacy (Job, 1992: 17).

Azar and Moon (1988a) refer to this as a 'software' factor. 'Popular support and acceptance', they contend, 'facilitate the smooth mobilization and allocation of domestic resources' (1988a: 81), which creates security for society, and this in turn creates security for regimes, since they do not need to fear being 
toppled by a dissatisfied population demanding more. But since 'demands for economic redistribution and political participation perennially outrun state capacities and create major overloads on political systems', such anxieties are a regular facet of regime security considerations (Ayoob, 1997: 128). ${ }^{19}$

Such concerns have been manifested in the public riots that occurred in several Arab countries in the 1980s, reflecting widespread anger and frustration - as, for instance, in Jordan in 1989, Egypt in 1986 and Algeria and Tunisia in 1988. In fact, there is little doubt among analysts that continued lack of legitimacy remains a problem for many, if not most, Arab regimes (Ibrahim, 1995; Korany, 1994).

The reasons for the riots have both an economic and a political strand: in the first place, poor economic performance has led to declining standards of living across the region. Population growth ${ }^{20}$ and urbanization, particularly in the non-oil states, in addition to placing heavy burdens on social welfare services, contribute to decline by forcing countries to significantly increase food imports (given that many Middle Eastern countries do not grow their own food), which results in higher foreign debts and an attendant loss of ability to fund domestic projects (see, for instance, Dessouki, 1993). The oil-rich states of the Persian Gulf have fared no better: here, economic mismanagement and declining gross national products and state revenues - while continuing military build-ups - have been the norm. At the same time those states have had to cope with greater expenditures because of regional conflicts - first by supporting Iraq against Iran in the 1980s, and then helping to finance the 1991 Gulf War against Iraq.

Politically, these have been manifested in a decreasing legitimacy accorded to the regime. Prior to these financial declines, the ability of states to secure exogenous geostrategic rents released governments from having to rely on domestic taxes for significant revenue, thus negating any domestic accountability (Anderson, 1995b: 32). ${ }^{21}$ This was accepted as a social contract of sorts, where, in return for quiescence in the political process, the government would provide for adequate socio-economic standards of living (al-Sayyid, 1999:49). ${ }^{22}$ But beginning with the Arab defeat in the 1967 war with Israel, these trade-offs began to be seen by the population as unworkable, since the defeat called into question the capabilities of the regimes (Ibrahim, 1993: 293). The inability to effectively deal with other regional conflicts also contributed to a decrease in legitimacy (Ibrahim, 1995: 34).

Despite the widespread government inefficiency and corruption, and human and civil rights abuses, among both the 'haves' and the 'have-nots' of the Arab world, however, the existence of these hardships do not of themselves provide the basis for regime insecurity. It is important to note that it is once the government is seen as not responding adequately to them that they form the basis of threats to regime security (Kazemi and Norton, 1999: 80). 
For a time, pressures for societal (and social) security and political rights were generally either ignored by Arab regimes or, more commonly, placated by focusing on external adventures or foreign policy goals, thus deflecting attention from the regimes' failures to achieve economic, social and political expectations. The Arab-Israeli conflict, in particular, was a 'stopgap, legitimacyrich mechanism' (Sela, 1998: 27), but other inter-Arab and inter-Muslim disputes were also used in this manner (Sela, 1998; Tessler and Grobschmidt, 1995: 144). As one study asserts, 'all Arab states tend[ed] to ensure regime security by provoking national security concerns' (Azar and Moon, 1988a: 83). ${ }^{23}$ The Palestine issue, for example, was often used to justify censorship and oppression to ‘strengthen' Arab states against Israel (Brynen, 1991: 607-9). ${ }^{24}$

This belligerence, it has been argued, is how regimes maintain their authority, and prove to their subjects that they are 'doing something', something worthwhile and deserving of resources and loyalty. It also means that they can use it as justification for repressing internal disagreement, in the name of the unity needed to face the external threat. Because of this, Lisa Anderson has argued, many regimes find foreign security threats easier to attend to than domestic threats engendered by inferior socio-economic conditions (Anderson, 1992: 166). However, such exercises in foreign policy sometimes lead to a serious depletion of state capacities. This in turn means there are less resources for citizens, which in turn leads to less legitimacy for the regime, as their policies are questioned and loyalty is declining (Azar and Moon, 1988a: 84. See also Lenore Martin's contribution to this volume.).

Some regimes opt, therefore, to enact political reforms, hoping that the illusion of effective political participation will satisfy pressures for change. As one observer has put it, "political reforms following mass riots are often carried out with the intention of manipulating the public and defusing serious crises of legitimacy and challenges to the rulers' hold on power' (Sadiki, 2000: 89). The uprisings in Jordan, for instance, were widely seen as a sign of the monarchy's declining legitimacy, because the rioters were mostly 'East Bankers', nonPalestinian Jordanians who traditionally formed the core of the Hashemites' strongest support group. Thus, the liberalization efforts after the riots were motivated by a need to reproduce some of this crumbling legitimacy (Rath, 1994: 553). In Egypt, public anger at the reported fixing of the 1995 parliamentary elections forced President Hosni Mubarak to decree a cabinet shuffle in January 1996, bringing in a prime minister who reached out, for a time, to some of the alienated groups.

However, such liberalizations have since been effectively negated by most Arab regimes (though some do still exist, as in Jordan and Egypt). Much of the clampdown on the reform processes can be traced back to the popularity of Islamic groups and their increasing strength in civil society. They have become the most robust source of opposition to the Arab regimes; in response, these 
regimes halted or slowed the liberalization process (Ghadbian, 1997), and many adopted harsh measures against the Islamic movements, which has an oppressive effect on the rest of civil society as well (see Kienle, 1998).

Preoccupied with the short-term, regime security remains the overriding priority for most, if not all, of the Arab states in the region, with the result that society's insecurities are significantly increased beyond 'normal' levels. Tracing Syria's process of state-building and national security, Volker Perthes draws the conclusion that the state's 'prime function, if not its raison d'être for those who control it, has been to serve ... regime security more than anything else', and that 'economic rationalities... have regularly been subordinated to the rationality of regime maintenance and control' (Perthes, 2000: 149); in other words, domestic socio-economic concerns are of secondary importance to regime security. In the case of Iraq, as another example, 'the sheer pervasiveness of coercion as an instrument of governance has ... erased the boundary between external and internal threats' (al-Khafaji, 2000: 259). This is evident in the circumstances that occurred after the 1991 Gulf War, when various segments of society attempted to rise up against Saddam Hussein, but ended up facing a Republican Guard that effectively defended the regime.

Regime legitimacy for Arab governments remains elusive, and indeed is coming increasingly under fire, as socio-economic problems continue to crop up or worsen, the answers to which regimes seem unable to provide and are increasingly unable to handle. Entrenched government corruption and inefficiency is only part of this: increasing globalization, through growing trade, increased availability of international, especially Western, television, use of technology - such as the Internet - and ease of travel, have contributed to the spread of alternative ideas from other parts of the world - including more politically and economically liberal ones. Moreover, Arab governments face a younger population than ever before, as well as one that is much better educated, more open to alternative ideas and more determined to demand change and effect it. At bottom, societies desire change, and many regimes in the Middle East are unwilling to grant it.

The discussion now turns to the case of the Palestinians to illustrate the arguments presented above.

\section{The Palestinians}

Many observers contend that despite their lack of statehood the Palestinians have a vibrant sense - and set - of democratic values and institutions, built up over the years in spite of conditions that might be expected to prohibit such institutions (in particular the Israeli occupation: see, for example, Brynen, 1995: 185; Shain and Sussman, 1998). The beginning of Palestinian self-rule in the mid-1990s also seemed to presage a healthy liberal-style democracy. 
Conditions have changed, however, since that period, and many analysts have pointed to a growing authoritarianism in the Palestinian areas that increasingly negates or ignores the political and civil rights of Palestinians under its rule.

Although the Palestinian Authority ${ }^{25}$ has not conformed to Western standards of democracy, including the social and economic dimensions normally attributed to 'real' democracy, it has adopted some of the liberalization efforts on which democracies are based - elections to the legislature, for example. In January 1996, elections to the Palestinian Legislative Council (PLC) took place; approximately 90 per cent of voters in the Gaza Strip and 70-80 per cent in the West Bank exercised their electoral rights, choosing an 88-member chamber whose power, it was believed, would be able to balance the PA's executive branch. These elections induced wide-ranging debate on a number of issues, a healthy sign of political liberalization (Abu-Amr, 1996: 83). The fact that Yasser Arafat did have a competitor in the presidential elections, despite his overwhelming victory, furthered this assessment.

Basing itself on authority through the people, the general view adopted by the PLC was that it would be in the vanguard of Palestinian democracy, and although it did not, or could not, always dissent from the PA's and Arafat's own policy decisions, it did qualify as an independent pole of opposition (Rubin, 1999: 27-44) - another hallmark of Western-style democracy.

Since then, however, political conditions have deteriorated into authoritarianism and suppression of efforts at political liberalization. There is no doubt that the Palestinian Authority has had, and will continue for the near future, to deal with very serious difficulties, any of which could easily hamper its continued development. These include: economic development; creating stable state and social structures and institutions; achieving unquestioned legitimacy in the eyes of its citizens; and, perhaps most importantly, genuine peace and normal relations with its historical enemy, the State of Israel. These are not easy tasks, but to succeed in them requires the PA to both maintain popular support and to build its state through progress in the peace process and by meeting its constituents' needs (see Rubin, 1999: 2 and chapter 1 generally for a fuller discussion on this). These tasks are difficult for any newly emerging state, but they are complicated in this instance by the fact that a state of Palestine does not yet exist: it does not have a territorially-defined mass, nor does it have the international recognition crucial for any new state to prosper in the international arena.

To succeed in these matters, some Palestinians have argued, the Palestinians would have to forgo some democratic aspects for the time being, in order to effectively mobilize its human and material resources to construct its state (see, for example, Rubin, 1999: 3; Brynen, 1995: 194). This seems to be the direction in which the PA is headed. Numerous examples support this. A restrictive Press and Publications Law was enacted by decree in $1995 .{ }^{26}$ Opposition 
and human rights activists and journalists have arbitrarily been arrested and detained without due process of law; newspapers have been shut down or heavily censored; and a High State Security Court impinges on a 'regular' judicial system. The PA has proposed a draft law that would constrain NGO independence and hamper their activities. In addition, several independent security agencies obstruct democratic practices. As well, the despotic tendencies of Arafat and the PA have hampered the effectiveness of Palestinian civil society. Women's groups, for instance, are very well organized in the Palestinian areas. Yet the PA has been ambivalent at best towards them, if not outright hostile, thus weakening them and their activities (Jamal, 2001). Some observers now believe that Palestinian politics is becoming increasingly authoritarian and despotic, as a result of the PA's attempts to consolidate its own power at the expense of political freedoms (Robinson, 1997). ${ }^{27}$

Similar to the methods employed by Arab regimes in the past, Arafat has asserted executive control in the name of achieving national goals, particularly against Israel (Shain and Sussman, 1998). The effort to write a 'basic law' for the expected Palestinian state is a good example of the PA's, particularly Arafat's, attempts to deflect political liberalizations and keep control within the executive. Since the lack of any constitution or, in the meantime, a transitional/provisional document, frees the PA from any institutional constraints on its powers, Arafat and the PA have resisted attempts to write one. ${ }^{28}$

An Amnesty International report contends that, since its very inception, the PA has 'progressively restricted the right to freedom of expression through a variety of means' (Amnesty International, 2000). Real or perceived criticism of the regime is often an excuse for harsh measures to be taken against the offending person or group. A November 1999 petition signed by twenty Palestinians, including members of the PLC and academics, for example, severely criticized the PA; as a result, eight of the signatories were detained, some for long periods of time, without any official reason (see Kershner, 2000: 26-8).

Faced with political stagnation and declining popular support, the PA has become less willing to support political liberalization and more willing to resort to authoritarian measures to enhance its position and implement its decisions (Brynen, 1995: 193-4). Such liberalization poses a threat to its decisionmaking capacity, and in response the PA (or, more appropriately, Arafat) has adopted a leadership style that has served to de-institutionalize Palestinian politics (Sayigh, 2001: 52). ${ }^{29}$

Rule by decree is still the most common form of policy making, the PLC having been sidelined and its role in the decision-making process cut out. ${ }^{30}$ It has, in effect, become 'a debating club whose resolutions are routinely ignored by the PA' (Robinson, 1997: 45). ${ }^{31}$ The PA has also lobbied to have international donors channel money through the PA itself, instead of through Palestinian 
NGOs, which would have the effect of negating any transparency in financial matters.

Because Palestinian society does not provide the PA with its income, as empirical examples from the rest of the Arab world have shown, the opportunities for demands for political participation are lessened due to a lack of necessary accountability. This has helped lead to near-complete control for Arafat - as one Palestinian magazine wrote: 'Arafat is the chairman of the PLO, the president of the PA; he holds all the reins, he controls all the money, he takes all the decisions ... and he, by and large, is the only law, whose authority is respected, established and enforced' (cited in Rubin, 1999: 4). ${ }^{32}$

The relationship between regime and society is tempered by the experiences of the forerunner of the PA, the Palestinian Liberation Organization (PLO), because of the impact of war and external rents that allowed the Palestinian leadership to neglect 'domestic' societal needs; and also because the PLO's particular system of political management until 1993 'means that a key struggle since 1994 has been over the definition (or restriction) of civil society and citizenship rights, leading to deepening schisms not only over constitutional arrangements but also over formal and informal mechanisms of social dispute resolution, gender and labor issues, and religion' (Sayigh, 2000: 234).

Hillel Frisch argues that the Palestinian regime is unlikely to last, on the basis of the conditions just outlined allied to the experience of other developing world countries: the authoritarian nature of the PA, he asserts, will suffer a long-term decline because of conflicts between regime and society, predicated on the growing demands of civil society and the regime's attempts to control or co-opt it (Frisch, 1998: 146).

This section was not intended as a judgement on the extent of liberalization achieved thus far in Palestinian politics; nor was its purpose to predict what a future Palestinian state would look like. This is too difficult a task, given the many and enormous undertakings faced by both society and polity in the years ahead and the constraints on their ability to perform these tasks. This includes a lack of finances, a lack of a contiguous territorial unit, an Israeli security presence in much of the West Bank, and ongoing (though at the time of writing, seemingly halted) peace negotiations with Israel on the very future of a Palestinian state. It can, however, be used as barometer for the theoretical arguments presented in the sections above.

\section{Conclusion}

This chapter does not intend to suggest that all authoritarian regimes in the Middle East, or the developing world as whole for that matter, will automatically take harsher repressive measures once demands for political liberalization 
are made and acceded to. Such an assertion is far too deterministic and ethnocentric, and is reminiscent of the political culture arguments against democratization in the Arab world. ${ }^{33}$ Rather, the purpose is to highlight the need to explain why some regimes act as they do (i.e. with repression), and why this is an important aspect for any understanding of security in the Middle East. Societies cannot be secure if their governments do not allow them to be. It is difficult to know in advance whether a regime that opens up the political arena will survive the process, for example, by being voted back into office. Some regimes might be; others might share some aspects of their current systems with newer, more liberalized, ones (for example, a monarchy in Jordan co-existing with a directly elected legislature with real powers to make laws and determine policy). Clearly, though, conditions cannot remain as they are if what this chapter argues is true: regimes will continue to feel insecure because of increasing demands by society, and, if they do not initiate political liberalizations to appease such demands or ease the political conditions within their countries, then they will respond with repression, which negates the security of societies.

As noted in the Introduction to this volume, many believe there is a danger of diluting the term 'security' so that it ceases to hold any analytical usefulness, and hence practical usefulness. Mohammed Ayoob points out that this danger can be somewhat avoided by arguing that issues only really become security issues when they 'demonstrate the capacity to immediately affect political outcomes' (Ayoob, 1997: 125). Although he does not specify what 'immediate' means, his argument can be taken to support the contention put forward here that societal and regime security, two factors that do affect political outcomes because of their linkage and their effects on the political process within states, should be considered part of the security lexicon.

The shift from a state-centric to individual- or group-centric analysis is not without its theoretical or practical problems. ${ }^{34}$ However, the purpose of this chapter is not to resolve all issues arising from redefining security, but rather to highlight the necessity of doing so. As chapter 1 argued, our purpose here is to act partly as a stepping-stone in the quest for epistemological and practical ends, and for others to build on such analyses to better understand security and contribute to resolving such complex conflicts as the Arab-Israeli conflict. In the end, despite the questions that some of the theoretical conceptions might raise in this chapter, and in the book as a whole, this is not an argument for retaining the traditional security studies concepts; it is, rather, an argument for more discussion and examination, in order to build better theories and understandings. As Kenneth Waltz (the most effective proponent of the realist paradigm and the most criticized for it) said, 'a theory applies only so long as the conditions it contemplates endure in their essentials' (Waltz, 1986: 340). Given the changed circumstances of the international system, and the distinctive nature 
of security in the developing world, a new theoretical understanding of security is necessary.

Two authors believe that Middle Eastern conflicts will now be primarily internal, pitting societies against their governments over social, economic and political empowerment (Norton and Wright, 1994-95: 7). At the same time, no study on Middle Eastern politics has concluded that regimes will give up their powers and positions in the near future, at least willingly; in fact, most observers believe the opposite.

Regime security is not usually thought to belong to the same class as other, more 'serious', security threats, such as the drug trade, global environmental problems, economic insecurity, and so on, because it refers to smaller groups of people, and generally applies to 'bad' objects, such as regimes that oppress or constrain their populations from actively participating in the full political, social and economic rights due them as citizens. But regime security is important, not only because it helps clarify the referent object of security, but also because regime insecurity leads to threats to societal security, in the form of oppression and violence against the populace, or at least certain segments of it (usually those individuals or groups demanding change or those communal groups different from the ruling clique).

As mentioned above, the difficulty in broadening a concept like security is recognized. In some cases, resistance to the inclusion of other referents and sources of security is justified, because of the inherent questions about what constitutes a security threat and how should it be responded to by policy makers. ${ }^{35}$ But this does not automatically preclude the broadening or deepening of the concept, since the concept as it developed during the Cold War era has become straight-jacketed into a typology that cannot account for conditions in the developing world. Traditional conceptions of security cannot account for individual or group security, thus such theories cannot account for what has been happening in states in the developing world, what has been a major feature of international politics since the end of the Cold War, including the Balkans, Africa, and the Middle East - where in many cases the state is 'captured' by various groups for their own use, which often results in increased insecurity for societal members who are not part of the dominant group. ${ }^{36}$ Realist attempts to explain these events often end up by describing such groups in state-like forms (see, for instance, Posen, 1993). Such analyses ignore not only the reasons behind such conflict (i.e. communal identity or societal insecurity), but even the effects of such security conceptions on society. Understanding how and why such shifts have taken place is part of redefining security. All this helps to provide different ways of looking at conflicts and how and why they begin, with the attendant hope that this will provide newer ideas for resolving such conflicts. Given the proliferation of intra-state security conflicts since the beginning of the 1990s, it is obvious that realist ideas have been sufficient neither to explain them 


\section{Effects of political liberalization}

nor to resolve them. That should be reason enough for attempts to redefine 'security'.

\section{NOTES}

1 Barry Buzan adds that this type of conceptualization also served American ideological and foreign policy agendas (1991: 11).

2 Larbi Sadiki points out that democratization in the Arab world has 'almost invariably' meant 'electoralization', without the corresponding benefits that are meant to accrue to societies with democratic systems (2000: 71).

3 It is recognized here that the level of political rights, hence of political liberalization, in Israel is open to debate, particularly regarding the non-Jewish citizens of the country. However there can be no doubt that this level is still much higher than in the Arab world, and for that reason Israel is not the focus of this chapter.

4 Critical security studies literature emphasizes the importance of the difference in processes of state formation in the West and in the developing world. In the former, hundreds of years of war making culminated in the nation state, the core of all practical and theoretical analyses of political entities since then. In the latter, it is pointed out, states' existence can be measured only in decades, and were usually not the result of warfare, but rather had their territory and boundaries drawn by inter-European politics, European strategic necessities, or European economic considerations.

5 The 'security dilemma', the result of the anarchic nature of the international system, was how realists formulated the link between states and security. Conditions of anarchy prompt states to seek to enhance their own security vis-à-vis other states; this in turn creates insecurity for other states. For a fuller explanation, see Robert Jervis (1978), 'Cooperation Under the Security Dilemma', World Politics, 30:1 (January), 167-214.

6 By 'developed' is meant the advanced industrial democracies of the West - Canada, the United States, Western Europe, Australia and New Zealand.

7 In Latin America, for instance, these circumstances are referred to as political pacts. See Frances Hagopian (1990), 'Democracy by Undemocratic Means? Elites, Political Pacts, and Regime Transition in Brazil', Comparative Political Studies, 23:2 (July), 14770 .

8 This is not to say that the state cannot be understood also as an actor in international relations; but it is to say that the sameness of regime and state is more important for understanding security in the developing world than in the developed areas.

9 For an argument about this concerning Africa, see Booth and Vale, 1997.

10 Although this formulation implies that peoples without states (such as the Palestinians, as yet) cannot ever be secure, this chapter does not focus on this particular, albeit very important, criticism.

11 Ayoob's definition of 'regime security' is somewhat different from that used here. For Ayoob, a security threat is so if it affects the regime's ability to carry out domestic or international politics (1997: 130). His focus is different from this project's: he reformulates the state and security to remain within a realist paradigm of security as threats that affect the state itself. Although his theoretical conceptions are precise, they do not conform to the understanding of security that this volume asserts, which is that there are various ways of understanding security, and all are important.

12 Most regime changes in the Middle East resulted in the deaths of former regime members; this is due to the nature of these changes, primarily by coups or revolutions.

13 For a good account of the types of economic and political liberalization methods regimes might employ, see Norton and Wright, 1994-95. 
14 Societal security is different from social security. The latter connotes public welfare service, while the former refers more appropriately to the subject of this chapter. Buzan, Waever and de Wilde also make this distinction (1998: 120).

15 See Ken Booth 1991 for a discussion on communal group security and a suggested solution-emancipation. Resolution of the insecurities examined here cannot be resolved as easily, since they are caught in a complex cycle of both the regime and the society.

16 Such arguments provide the basis for international humanitarian interventions. See, for example, Adam Roberts (1993), 'Humanitarian War: Military Intervention and Human Rights,' International Affairs, 69:3 (July), 429-49.

17 Numerous studies have used the Turkish example, in particular, in support of these arguments to explain the rise of political Islam and its successes. The conclusion is appropriate, however, for the entire region.

18 For an early account of these conditions, see Michael Hudson's seminal 1977 book Arab Politics, which argues that Arab politics is formed around growing societal demands and the inability of regimes to adequately respond to them, thus engendering a continual search for legitimacy.

19 Saad Eddin Ibrahim also points out that regional conflicts have also weakened the regime - not only by draining resources, but by exposing its impotence in handling these conflicts (1998: 377).

20 United Nations' estimates are that Egypt will almost double in population, to 120 million, by the middle of the century; Saudi Arabia will triple to 61 million in that time, and Syria and Iraq will hit 50 million. Cited in Maynes, 1998: 10.

21 For the Persian Gulf states, such rents came primarily from oil; for other Arab countries, these rents were procured mainly through dependence on one of the two superpowers or from other Arab states (primarily in return for being a 'front-line' state in the conflict with Israel).

22 This is basically an extension of 'rentier state' arguments that explain the lack of political participation as a result of the population's willingness (forced or otherwise) to forgo such participation because the government, through revenue (or rents) generated outside of the state, supplies its citizens with welfare services. Since the population does not produce the revenue that is used to implement state policy, it is assumed, it has no right to claim a role in determining policy. See, for example, Hazem Beblawi and Giacomo Luciani (eds) (1987), The Rentier State (London: Croom Helm).

23 Another study argues that more democratic governments in the Arab world would decrease the intensity of the Arab-Israeli conflict and contribute to its peaceful resolution - though at the same time, the authors do agree that this is not the only cause for the continuation of the conflict. The fault lies on both sides of the conflict, they contend, and there are numerous complex issues such an analysis ignores. But they do claim that increased liberalization would temper the hostility and create conditions for resolution. See Tessler and Grobschmidt, 1995.

24 For an account of Syrian strategies in this regard, see Perthes, 2000; for Iraq, see al-Khafaji, 2000.

25 When referring to the PA, this chapter points to the executive branch of the decisionmaking polity, for two reasons: one, it has usurped most of the powers granted originally to the Palestinian Legislative Council and makes most of the decisions that take place in Palestinian society, polity and economy; and, two, since the PA is the government of the (as-yet-undefined) Palestinian state, as is traditional in political science usage when discussing decisions of a political entity, the executive branch is the one mainly referred to. 


\section{Effects of political liberalization}

26 The Palestinian Centre for Human Rights has sharply criticized this law. See www.pchrgaza.org

27 Robinson reconfirmed this analysis a few years later, predicting that 'continued and strengthened authoritarianism is the most likely result in Palestine' (2000: 89).

28 For a good account of this, see Brown 2000. At the time of writing, no such document had yet been approved and ratified.

29 Palestinians themselves are aware of these constraints: A poll found that 60 per cent of Palestinians who had dealt with the PA believed it to be governed by 'favoritism, connection, bribery and other forms of corruption' (Robinson, 1997: 43; see also Shikaki, 1998: 39).

30 It does not, for example, have any control over the budget - traditionally a staple of legislative power.

31 For more examples of the struggle between Arafat and the PLC, and Arafat's repeated triumphs over the PLC's own proposed policies, see Rubin, 1999: chapter 2.

32 This is not the result of Arafat's tyrannical tendencies, Rubin goes on to write, but rather is due to his indecisive, yet impulsive, anti-institutional decision-making style (1999: 4). See also Sayigh, 2001; Abu-Amr, 1996: 91; and Rubinstein, 1995.

33 See Anderson, 1995a.

34 See Krause and Williams 1997: 46-7 for more explanation of some of these issues.

35 The literature on environmental security is a case in point, since 'environment' can include numerous sources of concern that might not be security threats, and the difficulty sometimes lies in where to delineate the two. For an account of these theoretical and practical problems (and a proposed solution), see Marc Levy (1995), 'Is the Environment a National Security Issue?', International Security, 20:2 (Autumn), 35-62.

36 See, for example, Douglas Chalmers, 1977. Although Chalmers was discussing Latin America, his idea of the politicized state can also be applied to the Middle East, where royal families or other groups tied together for various reasons have seized control of the state and held on to power with no intention of giving it up willingly.

\section{REFERENCES}

Abu-Amr, Ziad. (1996), 'Pluralism and the Palestinians', Journal of Democracy, 7:3 (July), 83-93.

Amnesty International. (2000), 'The Palestinian Authority: Silencing Dissent', (September). Available online: http://web.amnesty.org/ai.nsf/index/mde210162000?opendocument $\&$ of $=$ countries $\backslash$ palestinian+authority

Anderson, Lisa. (1995a), 'Democracy in the Arab World: A Critique of the Political Culture Approach', in Rex Brynen, Bahgat Korany and Paul Noble (eds), Political Liberalization and Democratization in the Arab World, Volume 1: Theoretical Perspectives, Boulder CO: Lynne Rienner Publishers, 77-92.

Anderson, Lisa. (1995b), 'Peace and Democracy in the Middle East: The Constraints of Soft Budgets', Journal of International Affairs, 49:1 (Summer), 25-44.

Ayoob, Mohammed. (1997), 'Defining Security: A Subaltern Realist Perspective', in Keith Krause and Michael C. Williams (eds), Critical Security Studies, Minneapolis: University of Minnesota Press, 121-46.

Ayoob, Mohammed. (1995), The Third World Security Predicament: State Making, Regional Conflict and the International System, Boulder: Lynne Rienner Publishers.

Azar, Edward E. and Chung-in Moon. (1988a), 'Legitimacy, Integration and Policy Capacity: The "Software" side of Third World National Security', in Edward E. Azar and Chung-in 
Moon (eds), National Security in the Third World: The Management of Internal and External Threats, Chelteuham: Edward Elgar Publishing Limited, 77-101.

Azar, Edward E. and Chung-in Moon. (1988b), 'Rethinking Third World National Security', in Edward E. Azar and Chung-in Moon (eds), National Security in the Third World: The Management of Internal and External Threats, Chelteuham: Edward Elgar Publishing Limited, 1-13.

Booth, Ken. (1991), 'Security and Emancipation', Review of International Studies, 17:4 (October), 313-26.

Booth, Ken and Peter Vale. (1997), 'Critical Security Studies and Regional Insecurity: The Case of Southern Africa', in Keith Krause and Michael C. Williams (eds), Critical Security Studies, Minneapolis: University of Minnesota Press, 329-58.

Brown, Nathan J. (2000), 'Constituting Palestine: The Effort to Write a Basic Law for the Palestinian Authority', Middle East Journal, 54:1 (Winter), 25-43.

Brumberg, Daniel. (1995), 'Authoritarian Legacies and Reform Strategies in the Arab World', in Rex Brynen, Bahgat Korany and Paul Noble (eds), Political Liberalization and Democratization in the Arab World, Volume 1: Theoretical Perspectives, Boulder CO: Lynne Rienner Publishers, 229-59.

Brynen, Rex. (1995), 'From Occupation to Uncertainty: Palestine', in Rex Brynen, Bahgat Korany and Paul Noble (eds), Political Liberalization and Democratization in the Arab World, Volume 2: Comparative Experiences, Boulder CO: Lynne Rienner Publishers, 185-202.

Brynen, Rex. (1992), 'Economic Crises and Post-Rentier Democratization in the Arab World: The Case of Jordan', Canadian Journal of Political Science, 25:1 (March), 69-97.

Brynen, Rex. (1991), 'Palestine and the Arab State System: Permeability, State Consolidation and the Intifada', Canadian Journal of Political Science, 24:3 (September), 595-621.

Brynen, Rex, Bahgat Korany and Paul Noble. (1995), 'Introduction: Theoretical Perspectives on Arab Liberalization and Democratization', in Rex Brynen, Bahgat Korany and Paul Noble (eds), Political Liberalization and Democratization in the Arab World, Volume 1: Theoretical Perspectives, Boulder: Lynne Rienner Publishers, 3-27.

Buzan, Barry. (1991), People, States and Fear, 2nd edn., Boulder CO: Lynne Rienner Publishers.

Buzan, Barry, Ole Waever and Jaap de Wilde. (1998), Security: A New Framework for Analysis, Boulder CO: Lynne Rienner Publishers.

Chalmers, Douglas. (1977), 'The Politicized State in Latin America', in James Malloy (ed.), Authoritarianism and Corporatism in Latin America, Pittsburgh: University of Pittsburgh Press, 23-45.

Dahl, Robert A. (1971), Polyarchy: Participation and Opposition, New Haven, CT: Yale University Press.

Dalby, Simon. (1997), 'Contesting an Essential Concept: Reading the Dilemmas in Contemporary Security Discourse', in Keith Krause and Michael C. Williams (eds), Critical Security Studies, Minneapolis: University of Minnesota Press, 3-31.

Denoeux, Guilain P. (1996), The United States and the Challenge of Democratization in the Arab World, Washington, DC: Georgetown University, Center for Contemporary Arab Studies.

Dessouki, Ali E. Hillal. (1993), 'Dilemmas of Security and Development in the Arab World', in Bahgat Korany, Paul Noble and Rex Brynen (eds), The Many Faces of National Security in the Arab World, New York: St. Martin's Press, 76-90.

Frisch, Hillel. (1998), Countdown to Statehood: Palestinian State Formation in the West Bank and Gaza, Albany: State University of New York Press.

Ghadbian, Najib. (1997), Democratization and the Islamist Challenge in the Arab World, Boulder CO: Westview Press.

Halliday, Fred. (1995), 'International Relations and its Discontents', International Affairs, 71:4 (October), 733-46. 


\section{Effects of political liberalization}

Hoffmann, Stanley. (1977), 'An American Social Science: International Relations’, Daedalus, $51,41-59$.

Holsti, Kalevi. (1991), Peace and War: Armed Conflicts and International Order, 1648-1989, Cambridge: Cambridge University Press.

Hudson, Michael. (1991), 'After the Gulf War: Prospects for Democratization in the Arab World', Middle East Journal, 45:3 (Summer), 407-26.

Hudson, Michael. (1977), Arab Politics: The Search for Legitimacy, New Haven CT: Yale University Press.

Ibrahim, Saad Eddin. (1998), 'The Troubled Triangle: Populism, Islam and Civil Society in the Arab World', International Political Science Review, 19:4 (October), 373-85.

Ibrahim, Saad Eddin. (1995), 'Liberalization and Democratization in the Arab World: An Overview', in Rex Brynen, Bahgat Korany and Paul Noble (eds), Political Liberalization and Democratization in the Arab World, Volume 1: Theoretical Perspectives, Boulder CO: Lynne Rienner Publishers, 29-57.

Ibrahim, Saad Eddin. (1993), 'Crises, Elites, and Democratization in the Arab World', Middle East Journal, 47:2 (Spring), 292-305.

Jamal, Amal. (2001), 'Engendering State-Building: The Women's Movement and GenderRegime in Palestine', Middle East Journal, 55:2 (Spring), 256-76.

Job, Brian. (1992), 'The Insecurity Dilemma: National, Regime, and State Securities in the Third World', in Brian Job (ed.), The Insecurity Dilemma: National Security of Third World States, Boulder CO: Lynne Rienner Publishers, 11-35.

Kazemi, Farhad and Augustus Richard Norton. (1999), 'Political Challenges to Middle East Governments in the Twenty-First Century', in Lenore G. Martin (ed.), New Frontiers in Middle East Security, New York: St. Martin's Press, 79-104.

Kershner, Isabel. (2000), 'Sounding the Alarm', The Jerusalem Report, 31 January, 26-8.

al-Khafaji, Isam. (2000), 'War as a Vehicle for the Rise and Demise of a StateControlled Society: The Case of Ba'thist Iraq', in Steven Heydemann (ed.), War, Institutions, and Social Change in the Middle East, Berkeley: University of California Press, 258-91.

Kienle, Eberhard. (1998), 'More than a Response to Islamism: The Political Deliberalization of Egypt in the 1990s', Middle East Journal, 52:2 (Spring), 219-35.

Korany, Bahgat. (1994), 'Arab Democratization: A Poor Cousin?', PS: Political Science \& Politics, 27:3 (September), 511-13.

Krause, Keith and Michael C. Williams. (1997), 'From Strategy to Security: Foundations of Critical Security Studies', in Keith Krause and Michael C. Williams (eds), Critical Security Studies, Minneapolis: University of Minnesota Press, 33-59.

Linz, Juan J. and Alfred Stepan. (1996), 'Toward Consolidated Democracies', Journal of Democracy, 7:2 (April), 14-33.

Maynes, Charles Williams. (1998), 'The Middle East in the Twenty-First Century', Middle East Journal, 52:1 (Winter), 9-16.

Middle East Report. (1998), 'Behind the Ballot Box: Electoral Engineering in the Arab World', by Marsha Pripstein-Posusney (Winter). Available online: http://www.merip.org/mer/ mer209/marsha.htm

Norton, Augustus Richard. (1995), 'Introduction', in Augustus Richard Norton (ed.), Civil Society in the Middle East, Leiden, The Netherlands: E. J. Brill, 1-25.

Norton, Augustus Richard and Robin Wright. (1994-95), 'The Post-Peace Crisis in the Middle East', Survival, 36:4 (Winter), 7-20.

Perthes, Volker. (2000), 'Si Vis Stabilitatem, Para Bellum: State Building, National Security, and War Preparation in Syria', in Steven Heydemann (ed.), War, Institutions, and Social Change in the Middle East, Berkeley: University of California Press, 149-73. 
Posen, Barry. (1993), 'The Security Dilemma and Ethnic Conflict', Survival, 35:1 (Spring), 27-47.

Rath, Katherine. (1994), 'The Process of Democratization in Jordan', Middle Eastern Studies, 30:3 (July), 530-57.

Robinson, Glenn E. (2000), 'Palestine After Arafat', The Washington Quarterly, 23:4 (Autumn), 77-90.

Robinson, Glenn E. (1997), 'The Growing Authoritarianism of the Arafat Regime', Survival, 39:2 (Summer), 42-56.

Rubin, Barry. (1999), The Transformation of Palestinian Politics: From Revolution to StateBuilding, Cambridge, MA: Harvard University Press.

Rubinstein, Danny. (1995), The Mystery of Arafat, trans. Dan Leon, Vermont: Steerforth Press.

Sadiki, Larbi. (2000), 'Popular Uprisings and Arab Democratization', International Journal of Middle East Studies, 32:1 (February), 71-95.

Sayigh, Yezid. (2001), 'Arafat and the Anatomy of a Revolt', Survival, 43:3 (Autumn), 47-60.

Sayigh, Yezid. (2000), 'War as Leveler, War as Midwife: Palestinian Political Institutions, Nationalism, and Society Since 1948', in Steven Heydemann (ed.), War, Institutions, and Social Change in the Middle East, Berkeley: University of California Press, 200-39.

al-Sayyid, Mustapha Kamel. (1999), 'Legitimacy and Security in Arab Countries, 1989-1996', in Lenore G. Martin (ed.), New Frontiers in Middle East Security, New York: St. Martin's Press, 47-77.

Schwedler, Jillian. (1995), 'Introduction: Civil Society and the Study of Middle East Politics', in Jillian Schwedler (ed.), Toward Civil Society in the Middle East? A Primer, Boulder CO: Lynne Rienner Publishers, 1-30.

Sela, Avraham. (1998), The Decline of the Arab-Israeli Conflict: Middle East Politics and the Quest for Regional Order, Albany: State University of New York Press.

Shain, Yossi and Gary Sussman. (1998), 'From Occupation to State-Building: Palestinian Political Society Meets Palestinian Civil Society', Government and Opposition, 33:3 (Summer), 275-306.

Shikaki, Khalil. (1998), 'Peace Now or Hamas Later?', Foreign Affairs, 77:4 (July-August), 29-43.

Sivan, Emmanuel. (1997), 'Constraints and Opportunities in the Arab World', Journal of Democracy, 8:2 (April), 103-13.

Tessler, Mark and Marilyn Grobschmidt. (1995), 'Democracy in the Arab World and the Arab-Israeli Conflict', in Mark Tessler and David Garnham (eds), Democracy, War, and Peace in the Middle East, Bloomington: Indiana University Press, 135-69.

Walt, Stephen M. (1991), 'The Renaissance of Security Studies', International Studies Quarterly, 35:2 (June), 211-39.

Waltz, Kenneth N. (1986), 'Reflections on Theory of International Politics: A Response to My Critics', in Robert Keohane (ed.), Neorealism and its Critics, New York: Columbia University Press. 